\title{
Ho Chi Minh's thought about cultural diplomacy
}

Vu Kim Diem ${ }^{1}$, Do Thi Ngoc Quy ${ }^{2}$

${ }^{1,2}$ KienGiang University (KGU), KienGiang, Vietnam

Email: vkdiem@vnkgu.edu.vn ${ }^{1}$;dtnquy@vnkgu.edu.vn ${ }^{2}$

\begin{abstract}
Ho Chi Minh's thought is a comprehensive and profound system of views on the fundamental issues of the Vietnamese Revolution, the result of the creative application and development of Marxism-Leninism in specific conditions of Vietnam in each stage of the revolution to ensure the victory of the resistance war and successful national construction. Today, domestic and world conditions have changed deeply, but Ho Chi Minh's ideology in general and Ho Chi Minh's ideology in particular still have great significance. The diplomatic culture was formed and developed with the process of forming his thoughts on the path of national liberation and socialist nation-building in Vietnam. This study provides a general overview of Ho Chi Minh's thoughts on diplomatic culture and assesses the current status of the process of applying those perspectives to Vietnam's current diplomatic culture.
\end{abstract}

Keywords: Ho Chi Minh's thought,cultural diplomacy, develop the country, Vietnam today

\section{Introduction}

Ho Chi Minh is a great leader of the Vietnamese people and the founder of modern Vietnamese diplomacy. His diplomatic culture that can brings special values expressed through ideology, activities, knowledge, language, art and applied style. These values need to be further confirmed, applied and developed during diplomatic activities in Vietnam has contributed to establishing the position and strength of the country in the international arena, concurrently creating trust and respect for people in the countries fighting for peace, national independence, democracy and social progress.

Two research questions are revealed as following:

Question 1:What was the content of Ho Chi Minh's thoughts on cultural diplomacy?

Question 2: What is the value of Ho Chi Minh's cultural and diplomatic values to Vietnam today?

\section{Literature Review}

W.J.Duiker has no sympathy for communism but has been intrigued by Ho Chi Minh's diplomacy since working at the US embassy. He has a unified view with many other researchers when he said that Ho Chi Minh built his thoughts based on cultural diversity. Ho Chi Minh was not only a patriot and communist house, but also a great cultural house. He even emphasized, on 
the world level, the image of Ho Chi Minh as a quintessential figure of the twentieth century. Ho Chi Minh represents the voice of the future (William, 2001: 167).

Pierre Brocheux, a French historian, has faithfully and vividly portrayed the image of Ho Chi Minh in real life but extremely legendary, Outstanding is the blending between the image of historical people and cultural people with a great cultural style, excellent cultural behavior. Though Pierre Brocheux's speech or research results did not once mention the concept of Ho Chi Minh's diplomatic culture, it is clear that in those assessments, the shadow of Ho Chi Minh's diplomatic culture appears quite clear - An honest, loving and special person with a very cultural behavior style (Pierre, 2007).

HellmutKapfenberger - Famous German journalist, writer, reporter, recreated the biography of an extraordinary but so simple character, a communist soldier, a patriot and a model. , "Tan thien tan my" about revolutionary moral qualities. The author commented, Ho Chi Minh has experienced life in the world, opened his heart to the world, opend his heart to the world, enjoyed a great education. The humanistic thought, warm human love, natural modesty and unadulterated integrity make Ho Chi Minh outstanding. The author's comments make people heartbreaking, contributing to affirm the core values Ho Chi Minh is conveying that has reached the heart and reason of humanity (Hellmut, 2010).

Domestically, Trinh Thanh Mai points out, at diplomat Ho Chi Minh there is natural and skillful combination of cultural and diplomatic elements. After discussing the basic content, the author focuses on researching the implementation of Ho Chi Minh's operating culture and the problems posed on the basis of solutions to improve the quality of applying Ho Chi Minh culture diplomacy, develops cultural diplomacy in Vietnam in the international integration period. Although the author discussed Ho Chi Minh's cultural diplomacy, some of the contents analyzed and interpreted Ho Chi Minh's cultural diplomacy need to inherit and exploit the work of researching Ho Chi Minh diplomatic culture (Virgin, 2019).

The author $\mathrm{Vu}$ Khoan comment that many thoughts of Ho Chi Minh and was and doing applied creatively by the Communist Party of Vietnam in practice, bringing great success. The author asserted that the application created "the Vietnamese diplomacy school". It is also "Ho Chi Minh's school of diplomacy" (Ministry of Foreign Affairs, 1995: 296). The author's point of view clearly demonstrates the significance and importance of applying Ho Chi Minh's thought and affirms that Vietnamese diplomacy has its own nuances. Author Vu Khoan and many other scholars focused on clarifying the diplomatic situation of Vietnam in the current period and agreed to evaluate:Today, implementing the foreign policy of expansion, multilateralization and diversification of national relations, Vietnam's diplomacy still maintains an independent national organization, national sovereignty and security;preserve and develop Vietnam's identity in the process of creating a favorable international environment for the cause of national construction and defense. Because we know how to harmoniously combine the trend of international integration with maintaining national identity, we have achieved great successes in terms of socio-economic construction, ensuring political stability and strengthening foreign relations. 
Author Pham GiaKhiem explains the issue in the length of history, connecting the past with the present and the future, arousing the compassion of each person about a Vietnam that has caused a lot of sympathy and won love. international friends. Today, Vietnam needs to show its friends a Vietnam with a rich history and culture, heroic historical sites, a country with strong vitality, rich potentials and achievements in innovation. , friendly people, love of peace, gratitude, loyalty. What should Vietnam do to continue to preserve that love (Pham, 2015: 511517).

Besides, author Pham Binh Minh attaches great importance to evaluating the successful lessons and learning experiences in implementing foreign affairs of the country since the 11th Party Congress, actively contributing to the preparation of the Grand Congress. National Congress XII and approved the country's foreign policy for the new period. The author discusses the content establishing Vietnam's international position on the path of development, at the same time emphasizing that international position is an important basis for the realization of national and national interests in foreign relations. Raising the position and promoting influence on the international arena is the foreign goal pursued by all countries. To establish and enhance its status, each country must rely on national synergy. The author stated that more than ever, the diplomatic front should maintain its sovereign role in the cause of defending the independence, sovereignty, unity and territorial integrity of the country. While putting the national interests first, it is necessary to continue to raise the banner of peace, stability and cooperation, harmoniously handle the relationship between the national interests and the common interests of the nation. the whole regional community (Pham, 2015: 286-287).

Some other researches and articles clarify theoretical and practical issues of the process of building and implementing the independent, autonomous and creative foreign policy of the Party and State of Vietnam. Male; characteristics and characteristics of modern Vietnamese diplomacy, achievements and diplomacy lessons from which to propose the development orientation of Vietnam's diplomacy in the new situation. These are: "Active diplomacy, actively mobilizing, building and taking advantage of new opportunities to build and defend the country" (Trong, 2014) of author Nguyen PhuTrong; "Diplomacy of Vietnam 1945 - 2000" (Nguyen, 2015). This is a rich source of documents providing materials and arguments for a more accurate and complete assessment of the new international context and problems posed in modern diplomacy.

In summary, these works have a positive reference value, providing arguments and arguments for the assessment of the current situation and the application of Ho Chi Minh's diplomatic culture in the context of international integration the current in Vietnam.

\section{Research Method}

\section{Method and Data}

The method used in this research is qualitative analysis and explanatory research. The analysis process was carried out by using historical information and with historical and dialectical materialism methods. 


\section{Results and Discussion}

\section{The content of Ho Chi Minh's thoughts on cultural diplomacy}

Diplomatic culture is cultural expression in the diplomatic field. According to WilfriedBolewski: Diplomatic culture is reflected in the way of thinking, speaking and behaving in diplomatic activities (Tran, 2014: 11-12).Or there is a cultural view of diplomacy that is the behavioral style and expression of diplomats in the working process ( $\mathrm{Vu}, 2014)$.

Or there is a point of view: Diplomatic culture "is not a separate culture and external of the diplomatic and foreign affairs sector but the expression of Vietnamese cultural values that have permeated into thought, wisdom, style of organizations and individuals doing diplomatic work, both State diplomacy and people's diplomacy" (Pham, 2008: 46) and "Diplomatic culture is heavy on highly qualified manners, civilized expression, at the same time showing pure fine customs. It can be called the diplomatic demeanor"(Pham, 2008: 30).

Thus, diplomatic culture is the cultural behavior of officers doing diplomatic work. . Diplomatic culture tends to behave at a high level, which is the behavior between people and people, between people and communities, and among ethnic communities at the elite level, cultural behavior. - culture in diplomacy.

From patriotism, Vietnamese cultural traditions and on the basis of Marxist-Leninist methodology, with seasoned bravery and extremely rich experience through decades of revolutionary activities, Ho Chi Minh left the modern Vietnamese diplomacy a unique diplomatic ideology - Ho Chi Minh's cultural and diplomatic ideology, with the following basic contents:

First, the thought combines national power and era power. Independence, self-reliance and self-reliance associated with solidarity and international cooperation are key ideas in the policy of combining national strengths and the strengths of the times.In which, the main thought is independence, self-reliance, self-resilience associated with solidarity and international cooperation. Ho Chi Minh, emphasizing "Make friends with all democratic countries and not make hatred towards anyone" (Ho, 2011, vol 5: 256). He attaches great importance to friendship and cooperation with neighboring countries sharing the same border; expanding relations with countries in the region and around the world; well handling relations with major countries to serve the revolutionary interests. In addition, in a culture of diplomacy with other countries, "with strong strength, diplomacy will win. Strength is the gong, diplomacy is the sound. The gong is loud, the sound is loud "(Ho, 2011, vol 4: 147). Along with that, Ho Chi Minh has focused on building and promoting the strength of people's foreign affairs, thereby mobilizing the people of the world to support Vietnam against French colonialism and the American imperialism. He stated: "The strength, greatness and resilience of the Vietnamese people are basically the unity of the Vietnamese people and the support of the people of the world ..." (Ho, 2011, vol15: 675). Ho Chi Minh's view of combining national strength and era strength is Marxist's view of conflict resolution based on the decisive role of internal factors and the impact and influence of external factors. 
Second, in terms of diplomatic method, he determined that the diplomatic culture must be a front, a constituent army of the Vietnamese revolution, skillfully combining "both fighting and talking", combining national strength. with the power of the times to create great synergy. He always puts Vietnam in the flow of the world, attaches great importance to power centers and big trends. The special person emphasizes "immutability, adaptability", taking the unchangeable to cope with all changes, maintaining the principle, steadfastness and stability of strategic goals with flexibility, the flexibility of the revolutionary strategy. Ho Chi Minh's diplomatic method also demonstrates our nation's peace-loving tradition, striving to settle disputes by peaceful means.

On the basis of national culture, Ho Chi Minh's diplomacy style is imbued with the quintessential cultural value of humanity, perfectly combining East-West culture. In terms of thinking, he advised to have a comprehensive perspective, "look closely and carefully" to clearly see the general trend and the trend of social progress. In his behavior, he harmoniously combines national and international values, making everyone feel close and intimate. In communication, the User has an idyllic manner to effectively convey diplomatic messages. In particular, Ho Chi Minh has manipulated smoothly the "five knowing" (know himself, know people, know the times, know how to stop and know), is the ability to create opportunities and take the opportunity, as diplomacy work helps to win people's hearts with righteousness, human love, reason and morality. The achievements of Vietnam's foreign relations in the cause of national liberation, national reunification and defense of our country have clearly demonstrated Ho Chi Minh's ingenuity in applying diplomatic arts to bring ways to network to success.

In particular, Ho Chi Minh's diplomatic culture is shown in the method of "Immutable immutability". This is a method that combines closely between traditional diplomatic knowledge steadfast in principle, flexible in strategy with Marxist materialistic dialectics, Ton Tu martial arts...This combination gives Ho Chi Minh's diplomatic method scientific and practical. Same worldview of dialectical materialism, Ho Chi Minh used the method "Immutable immutability" to successfully solve the practice of national diplomacy. Ho Chi Minh conceived: "Our principles must be solid, but our strategies are flexible" (Ho, 2011, vol 8: 555). That is, the basic, long-term goal remains unchanged, but the concrete, immediate goal can change. The way of showing is to choose the order of priority, the level of requirements needs to be flexible depending on the correlation of domestic force and international circumstances, grasping the opportunity to transform the force into the world. The principle of "Immutability invariant" Ho Chi Minh applied smoothly in diplomacy.

Ho Chi Minh is imbued with the folk philosophy "Live in a gourd, you grow round. Live in a tube, you grow long" ("Ở bầuthìtròn, ở ốngthìdài"), in the diplomatic method is always pliable and flexible, ready to do any way to bring benefits to the people. Ho Chi Minh attaches great importance to the flexible diplomatic method," lay nhuthangcuong". This method is not only theoretically correct, but also close to the practical characteristics of Vietnam. A French journalist commented: "It is the combination that not everyone can imitate between flexibility with stubbornness, between political flexibility and principled rigidity, between the use of patriotic traditions and analysis Marxism created the uniqueness of Mr. Ho Chi Minh"(Song, 
2005: 336). Diplomacy doesn't always follow others. Ho Chi Minh was pliable but not weak, flexible, but not inclined, losing his stance.

The tradition of his father's diplomatic struggle formed a method of persistent principle, but flexible, soft and skillful policy. In the resistance wars, the "bat bien" thing is that we persist in the issues of independence, sovereignty, unity, flexibility, and "van bien" in the tactic strategy.

Third, peaceful thoughts, more friends and less enemies. From the revolutionary situation, sometimes having to deal with many opponents, Ho Chi Minh highlighted the motto "... make our country less enemies and more friends" (Communist Party of Vietnam, 2000 : 27).HồChí Minh clearly distinguishes between friends, enemies, close friends, seeking ways to reduce enemies, to focus on fighting with the main enemy. While still in prison in China (1942-1943), he showed solidarity with the anti-colonial movement of India. In 1944, he personally brought lieutenant pilot W. Shaw to Con Minh and handed it over to the US, thereby allowing the Americans to understand the war of Vietnam under the leadership of the Viet Minh Front. He also educated our people to clearly distinguish friends and foes, differentiate between the French colonialists and the American imperialists from the French people and the American people to take advantage of their solidarity and support of them, isolate and take part in the fight painting into French colonialism and American imperialism.

\section{The value of Ho Chi Minh's cultural and diplomatic values to Vietnam today}

Ho Chi Minh's thought about diplomatic culture is a rich, profound and comprehensive system of views; is an important foundation for the Party and State to plan diplomatic strategies in the past years and the coming time. Recognizing the role of diplomatic culture with the Vietnamese revolution, on the basis of inheriting the diplomatic inheritance of the national tradition, bearing the mark of the diplomatic culture of Ho Chi Minh: Rich in humanity, peaceful friendship , flexibility, tolerance, legal basis, "fundamental principles of international law, equality, mutual benefit... peace, cooperation and development" (Communist Party of Vietnam, 2016: 34-35). An active and proactive diplomacy in establishing genuine and sincere international relations, expressing the spirit of Vietnam, the responsibility of Vietnam "contributes to the cause of peace, national independence and democracy. and social progress in the world"(Communist Party of Vietnam, 2016: 35).

In the process of international integration, Vietnam has been promoted in both thinking and practice, has strongly shifted from the scope of "economic integration" to "comprehensive integration" with the main contents: economics, politics, defense-security, culture - society, education - training, science - technology and other fields such as labor, health, sports ...In political and defense-security cooperation, Vietnam has actively participated in mechanisms such as the ASEAN Political-Security Community (APSC), the ASEAN Amity and Cooperation Treaty (TAC, 1976), and the Southeast Asia Nuclear Weapons-Free Area Convention (SEANWFZ, 1995) as well as security Dialogue mechanisms such as ASEAN Regional Forum (ARF), ASEAN Defense Ministers Meeting (ADMM), Ministerial Conference ASEAN Defense Minister Open (ADMM +), East Asia Summit (EAS). 
Vietnam's international integration process is increasingly deep and effective. Economically, Vietnam has become an important link in many economic links through the signing of many free trade agreements, thereby creating a great driving force for development. The International Monetary Fund (IMF) assessed that Vietnam is among the 20 economies with the largest contribution to global growth in 2019. Although the COVID-19 epidemic is causing the global economic slowdown, Vietnam still has a high growth rate in the region. International integration in politics - security - defense, society - culture and other fields has been increasingly deepened. . With a new position and force, Vietnam has actively participated in and contributed to most important international organizations and forums, successfully assumed many important responsibilities, is promoting the role of ASEAN President 2020 effectively and Non-permanent member of the United Nations Security Council for the term 2020-2021. Vietnam has been actively contributing to solving many important international issues such as: contributing to ensuring food security, promoting international cooperation to prevent the COVID-19 epidemic, promoting peace and reconciliation. on the Korean peninsula... according to the motto "must always persevere, calmly, wisely handle all complex matters, including sovereignty and territorial issues", "follow the motto" of constant immutability", especially keeping" hot heart, cold head "and" resolute, persistent "to handle external challenges" (Nguyen, 2016). Vietnam is showing a more proactive, strong and positive stance on issues of its core interests in order to lead public opinion, creating in the increasingly complex international environment, foreign relations have contributed effectively, result in firmly protecting the sovereignty and territorial integrity of the Fatherland.

We have made every effort to build a land border of peace, friendship and development with Laos, Cambodia and China. Facing the complexities in the South China Sea, we have correctly assessed the situation, struggled, handled in a timely manner, soberly, wisely, firmly, persistently, firmly defending sovereignty, territorial integrity, rights and legitimate interests of Vietnam at sea.

In addition to the above results, other important pillars and fields of foreign affairs have all achieved many achievements. Foreign affairs of the Party, State diplomacy, people's diplomacy, foreign affairs of the National Assembly, foreign defense and security were effectively implemented, closely and smoothly coordinated; economic diplomacy, cultural diplomacy, citizen protection, overseas Vietnamese work, and external information were also actively and actively implemented, making an important contribution to the overall external achievements of the land country.

On the threshold of the third decade of the 21st century, the world is witnessing great, profound and unpredictable changes. Peace, cooperation and development are still a big trend, but the COVID-19 pandemic has contributed to accelerating profound changes in the international arena, directly affecting the security and development environment of our country. We need to continue to apply creative Ho Chi Minh's cultural and diplomatic ideology to put Vietnam in the right "flow of the times", creating great power to bring the Vietnamese revolution to new victories. 


\section{Conclusion}

Ho Chi Minh's diplomatic culture contains profound values both in theory and practice. In terms of theory, the value of Ho Chi Minh's diplomatic culture expressed firstly is the crystallization of cultural quintessence, knowledge, national diplomatic experience with cultural quintessence, human diplomatic knowledge.

Diplomatic culture of Ho Chi Minh represents the diplomatic culture of the nation dealing with the world, participating in solving many problems in relations with international friends. Ho Chi Minh's diplomatic culture contains high and beautiful values that reflect the aspirations and development trends in progressive human international relations. Ho Chi Minh's diplomatic culture is not only a valuable heritage of the Vietnamese nation but also of humanity. It contains humanistic and humanitarian values of all times, bringing a spirit of community, towards common interests. Ho Chi Minh's diplomatic culture deeply expressed the great aspiration of progressive mankind to live together peacefully, to have sincere relations and cultural behavior.

Research and apply Ho Chi Minh ideology creatively on the basis of specific historical principles. Applying and developing Ho Chi Minh's ideology means that on the basis of mastering the revolutionary and scientific nature of Ho Chi Minh's thought, making that thought relevant and vividly attached in the context of specific history can. In addition, the construction and cultural diplomacy development of Vietnam have been complicated, new problems and events appear that the context of Ho Chi Minh's ideology has not yet existed. Fidelity to Ho Chi Minh's ideology requires on the basis of principled innovation, applying creatively, without stereotypes, to develop his ideology to suit the current economic situation.

\section{Acknowledgement}

We would like to express the anonymous research participants for their willingness to have taken part in this study. Additionally, our sincere gratitude should go to other relevant parties who have given comments and supported us during our study. Without their unconditional help and support, we would have never been able to finish this study.

\section{Conflit of interest}

The authors declare that they have no competing interests.

\section{References}

1. Communist Party of Vietnam. (2000). Party Documents: Complete set, Volume 8. Hanoi:National Politics.

2. Communist Party of Vietnam. (2016). Document of the 12 th National Congress of the Party. Hanoi: National Politics.

3. Hellmut, K. (2010). Ho Chi Minh - A chronicle. Hanoi: World.

4. Ho, C.M. (2011). Complete set, Volume 4. Hanoi: National Politics.

5. Ho, C.M. (2011). Complete set, Volume 5. Hanoi: National Politics. 
6. Ho, C.M. (2011). Complete set, Volume 8. Hanoi: National Politics.

7. Ho, C.M. (2011). Complete set, Volume 15. Hanoi: National Politics.

8. Jean, S. (translated by Kim Le,2004). The story of a peaceful peace miss. Hanoi: Public Security Publishing House and Phuong Nam Cultural Company.

9. Ministry of Foreign Affairs (1995), International integration and identity preservation. Hanoi: National politics - Truth.

10. Jame, L. (1967). Ho Chi Minh. Pari:Ed. Seuil.

11. Le Nouveau Petit Robert. (1994). Dictionnaires Le Robert. Paris.

12. Nguyen, D. B. (2015). Vietnam Diplomacy 1945 - 2000. Hanoi: National politics.

13. Nguyen, P. T. (2018). The full text of General Secretary Nguyen PhuTrong at the 30th Diplomatic Conference. https://baoquocte.vn/toan-van-phat-bieu-cua-tong-bi-thu-nguyenphu-trong-tai-hoi-nghi-ngoai-giao-30-76033.html

14. Pham, S. C. (2008), Cultural Diplomacy "For one copy Vietnamese identity in the international arena". Hanoi: The World Publishing House

15. Pham, G. K. (2015). Comprehensive Vietnamese diplomacy in times integration period. Hanoi: National politics - Truth.

16. Pham, B. M. (2015). Vietnamese diplomacy deployment process foreign policy of the XI National Congress of the Party. Hanoi: National politics - Truth.

17. Pierre, B. (2007). Ho Chi Minh: A Biography. Cambridge University Press.

18. Song, T.(2005). Ho Chi Minh - A brilliant thinker. Hanoi: Theory.

19. Tran, T. H. M. (2014). Diplomatic culture of Vietnam, Topic scientific research at ministerial level, the agency in charge of the Cultural External Relations Department UNESCO.

20. William, J. D. (2001). Ho Chi Minh: A life. New York: Hyperion. 